\title{
DOCUMENTARY LETTERS OF CREDIT, LEGAL NATURE AND SOURCES OF LAW
}

\author{
Hamed Alavi, \\ Tallinn Law School \\ Tallinn University of Technology
}

(Received January 2016; Accepted April 2016)

\begin{abstract}
There is no doubt about risky nature of international trade. Such risk can be conceptualized as country risk, transportation risk, customer risk and etc. Documentary Letters of Credit (LC) are used as a method of payment in international business for many centuries in order to reduce risk of trade specially when parties are located in different countries and do not have precise information from financial standing of each other. In such occasion LC will reduce the risk of trade by shifting payment obligation from buyer as an individual to a payment guarantee of a bank as a legal entity in return for presentation of complying documents with terms of credit by seller. Familiarity with legal nature and different legal frameworks which govern the international operation of documentary letters of credit can facilitate the process of international trade for businessmen and boost national economies. However, lack of knowledge about them can impose huge losses on international traders. Situation will be more complicated when we understand that there are many internationally recognized legal frameworks which can affect the operation of LC and they get frequently updated in order to address technological and economic developments in global market. In this paper, author tries to answer questions regarding (i) what are international legal frameworks governing operation of documentary letters of credit? (ii) which areas of LC operation has been covered by them and (iii) how do they address the legal questions regarding international operation of documentary letters of credit?
\end{abstract}

Key Words: Documentary Letters of Credit, Legal Framework, International Trade, Payment Risk.

\section{Introduction}

Documentary Credits, Documentary Letters of Credit or Banker's Documentary Letters of Credits are one of the old and well appreciated existing instruments for financing the international trade. Such long history of Documentary Letters of Credits has resulted in letting them to be considered as "Life Blood of Commerce" [1]. In terminology, Letter of Credits has roots in the French word 'Accredetif' with the meaning of power for doing something. However, Accredetif itself comes from 'Accreditiwus' in Latin which conveys the meaning of 'Trust' [2].

There is no doubt about historical uses of Letters of Credit in International Trade. Their usage in practice of international trade has been traced to banking systems of old Egypt and Babylon. Some excavations in Babylon provide evidences of promissory notes from 3000 B.C that show the promise for payment of exact 

Greece show drawing of Letter of Credits by banks to their correspondents in order to obviate the transport of Spices in return to payment of accounts [3].

During middle Ages, Letters of Credits were used in order to solve two distinctive trade problems. (A) Lack of security in carriage of precious items and gold by merchants during their business trips and (B) Lack of common trade currency for meeting the cash need of merchant's abroad [4]. Due to security risks of carrying cash in hand, merchants of those days were preferring to exchange their cash with a 'letter of credit' at their bank with the capability of being cashed in another bank at given destination [5].

According to the De Rover, Letters of Credit were in use by Medici Bank during late 1ate 1300s in Bruges and Italy [6]. In the course of time, London gained fame as an outstanding financial centre due to growth of international trade and raise of British Banking System as monopolistic issuer of Letter of Credit which was the a result of accepting Pound Sterling as currency for international trade created.

Letter of Credits entered United States of America after raising competition among factoring houses and acceptance of drafts against shipment [7]. In today's world, Letters of Credits are considered among the most attractive arears of research for legal, international trade and finance scholars. In this respect, Professor Roy Goode defines Documentary Letters of Credits as: "A money promise which is independent of the transaction that gives it birth and which is considered binding when received by the beneficiary without acceptance, consideration, reliance, or execution of solemn form" [8]. Latest version of Uniformed Customs and Practice for Documentary Credits (UCP 600) defines Letters of Credit as: "An arrangement however named or described, that is irrevocable and thereby constitutes and definite undertaking of the issuing bank to honour the complying presentation". Further, Article 2 of UCP 600 considers complying presentation as "a presentation that is in accordance with terms and conditions of the credit, the applicable provisions of this rule and international standard banking practice" [9]. Among other definitions, Kudriachov describes Letters of Credits as "one way abstract transaction, in which the emitting bank cannot reject the execution of its obligation by referring to non-execution of obligations by other parties to the transaction" [10] Although, Documentary Credits have very long mercantile history, their involvement to utilization of credit arrangements practically goes back to the second half of the $19^{\text {th }}$ century [11]. Therefore, current article tries to a review on general aspects of Letter of Credit operation, international legal frameworks applicable to LC transactions and main legal principles in operation of Letters of Credits. A review of legal history of Documentary Letters of Credits shows that Rose $v$ Von Mierop and Hopkins [12] is one of the first lawsuits on letters of credits and landmark of LCs Law in English legal system [13]. 
Hamed Alavi (2016)

Documentary Letters of Credit, Legal Nature and Sources of Law

\subsection{Functions and process of the operation in Documentary Credits}

Article 2 of UCP (600) defines parties to the Letter of Credit as following: "Applicant: the party to whose request the credit is issued. Beneficiary: The party in whose favour the credit is issued. Issuing Bank: Means the bank that issues a credit at the request of an applicant or on its own behalf" [14]. Basically, the process of issuing a Letter of Credit starts with request of Buyer (applicant or Account Party) to his bank (issuing bank) in order to issue a credit in favour of the seller (Beneficiary) based on the underlying contract of sales between parties. As a result, issuing bank will contact beneficiary in his country in order to inform him about opening the credit in his favour. Due to a geographical distance between issuing bank and beneficiary, advice of the credit to beneficiary will generally take place via a correspondent of issuing bank in beneficiaries country (advising bank). The responsibility of advising bank is only informing beneficiary about issuing credit in his favour and it does not have any obligation of payment towards beneficiary [15]. As a result, the legal nature of relationship between issuing bank and advising bank is considered as relationship between agent and principle [16].

Beneficiary seller at this stage must compare terms and conditions of the credit with terms of underlying contract. In case of any existing discrepancy at this stage, beneficiary is entitled either to reject the credit or require amendments. After approval of the credit by beneficiary, issuing bank will enter into a contract with Beneficiary to provide him with price of merchandise in return of complying documents required by the credit. As a result, any given credit will have at least three parties. Namely, Issuing bank, Beneficiary and Applicant.

However, in practice number of parties might be more than three. It might happen that issuing bank asks advising or any other bank in the country of seller to provide credit on her counter which is a very appreciated option for beneficiary who will be paid in his own country rather than the country of the buyer. In this case, the bank which provides credit on her counter is considered as Nominated Bank [17] In some occasions, seller might ask for higher guarantee for payment which is already provided by issuing bank. In this case a confirming bank will add her irrevocable commitment for payment of the credit to beneficiary in addition to issuing bank. As a result, any given Documentary Letter of Credit will consist of at least three independent contracts between Beneficiary and Applicant (Underlying Contract of Sales), Account Party and Issuing Bank, Issuing Bank and Beneficiary. However, in majority of cases number of contracts will increase relatively with the increasing number of involved parties in the credit after joining confirming bank and Nominated Bank to original parties to the Documentary Credits.

Enonchong [18] introduces four generic functions for the Letter for Credits. First, Letter of credit reduces commercial risk both for importer and exporter by providing security of payment for exporter and security against the non-delivery of 

him with cash flow while at the same time providing exporter with the chance to raise money before being paid by issuing bank. Third, Documentary Credits can be used as security for other obligations like case of Back-to-Back letter of credits. Fourth, is the function of documentary credits as conditional payment method and providing the possibility for seller to receive payment from importer in case the credit has been dishonoured by bank.

Function of Documentary Letters of Credit follows different steps of the Letter of Credit's process [19] Process starts with negotiation of the terms of contract by buyer and seller. They will enter the underlying contract of sales. According the underlying contract, exporter will undertake to provide confirmed goods which are subjected to that particular transaction and importer commits to pay the price of good via Documentary Letter of Credits. Further, information regarding the details of the Credit will be also mentioned in the underlying contract. As the second phase, the buyer will require the issuing bank to open a credit in favour of exporter. In case of issuing bank's agreement to issue the credit, Importer (account party) to pay him the price of goods sold to the importer in return of delivering confirming stipulated documents in the credit [20].

Although, these three independent contracts are considered as basic framework for function of Documentary Letter of Credits, but in practice, in majority of occasions, beneficiary will interact with a local bank in his own country rather than being involved directly with issuing bank. If parties decide so, then the advising bank will contact the beneficiary in order to inform him about the issuing of the credit in his favour. At the time that credit requires involvement of Nominated Bank and Confirming Bank, there will be a separate contract between Beneficiary and Nominated or Confirming Bank and Issuing Bank and Nominated and Confirming Bank. Advising Bank might or might not accept to act in the capacity of Nominated and /or Confirming Bank.

As a result, beneficiary ships goods for account party and provides confirming stipulated documents in the credit to the issuing bank, Nominated Bank or Confirming Bank. Nominated Bank will check presented documents and in case of conformity, they will pay beneficiary based on the authorisation in issuing bank [21], transfer documents to issuing bank and wait for reimbursement [22]. Issuing bank also check documents and in case of their conformity will reimburse Nominated or Confirming Bank, debit the account of applicant and inform him to come and receive his documents.

As it was mentioned earlier, most of the time credit will require the involvement of Nominated Bank and Confirming Bank as Issuing bank is not located in country of Beneficiary and it is difficult for him the confirm the authenticity of signatures by issuing bank [23]. 
Hamed Alavi (2016)

Documentary Letters of Credit, Legal Nature and Sources of Law

\section{Legal Nature and Sources of the Letter of Credit Law \\ 2.1. Background}

The exact time that Letters of Credits started to function as their modern form is not clear [24]. However, most researchers tend to agree that emergence of the modern letters of credits started from the middle of nineteenth century [25]. Reviewing the history of Documentary Letters of Credit, explains formation of modern forms of credit as response to demands in commercial world by developing primitive forms of credit [26]. However, comparison between Modern Documentary Credits and Open Credits as one of the ancients types of credit provided by banks to merchant in international trade shows the 'resemblance is only superficial' [27]:

"1) The object of today's letter of credit is to guarantee the payment of the purchase price in international sales of goods; the open letter of credit, on the other hand, was used to raise funds for merchants traveling overseas. A merchant who did not wish to carry cash but wished to obtain credit or cash in countries where it would have find it difficult to do so otherwise could ask his banker to issue an open letter of credit for him. On the faith of the open letter of credit, the merchant was able to obtain advances from foreign bankers against its drafts.

2) While the issuer of a modem letter of credit promises to pay a seller who has already entered into a contract for the sale of the goods provided the seller submits the required documents, the issuer of an open letter of credit asked others to advance money to his customer.

3) In a modern letter of credit the credit is given to some third party with whom the customer has some commercial dealings; in the open letter of credit the letter was given to the banker's customer." [28]

Reviewing the history of modern Letter of Credit also shows deference between their legal nature with other instruments used in international trade including negotiable instruments and Contracts of Sales.

\subsection{Sources of Letter of Credit Law}

In the course of history, development of law and regulations of the Documentary Letter of Credit was based on custom. However, in modern time; International Chamber of commerce has provided the major source of law for documentary letters of by assuming the responsibility for codification of relevant customs and usage under Unified Custom and Practices for Documentary Credits (UCP). Additional to UCP, International Chamber of Commerce has introduced other regulations including eUCP, Uniform Rules of Contract Guarantees, Uniform Rules for Demand Guarantees, ISP98, which is International Standby Practices for Independent Guarantees and Standby Documentary Credits. United Nations Conference for International Trade Law also individually took the initiative to prepare universal regulations for Independent Guarantees and Standby Letters of 

international frame works for regulation of documentary credits, this issue has been addressed in few national law systems. Among Civil Law countries only Colombia, El Salvador, Greece, Guatemala, Honduras, Lebanon, Mexico, and Syria have statutory rules on the letter of credit; and, the only country in the common law system is the United States. In other Common Law Countries including England, Legal issues of documentary credits are subjected to case law.

The main focus of current paper in this section will be study of different International legal sources for documentary credits, and also the answer of common law system to the question of legal framework for documentary credits.

\subsubsection{Uniform Customs and Practice for Documentary Credits (UCP)}

UCP is the product of harmonization process for international law in order to facilitate the process of international trade and reducing conflicts among different legal systems. By escalating amount of international trade at the beginning of $20^{\text {th }}$ century as the expected aftermath of industrial revolution first national attempts towards harmonization of Letter of Credit Law stated in 1920's. The process of harmonization of LC law at national level started in the United States of America by drafting relevant banking regulations for Letter of Credit Operation by New American Commercial Credit Conference [29] which was followed by European countries [30]. At international level, Amsterdam Conference of International Chamber of Commerce in 1929 was the first step where proposed law was adopted only by France and Belgium [31]. A revised version of the text was introduced in 1933 by the Commission on Banking Technique and Practice of the International Chamber of Commerce at Vienna Conference and received acceptance from some European countries and individual American banks [32]. Further revisions on the code by ICC started after the end of World War II. During Lisbon Conference of ICC in 1951 new revision of harmonized code for international operation of LC was introduced which was adopted by several African and Asian banks but got rejection by England. New revision of UCP took place in 1962 following the objective of receiving worldwide application [33] and received adoption by banks in Britain and Commonwealth countries. In 1974 the new revision of UCP was introduced in order to meet the global needs for container shipping and multimodal transport which received breakthrough achievement of being adopted by 162 countries [34]. Next revision in UCP happened in 1983 which is known as UCP 400 [35].Innovations introduced in UCP 400 were trying to cope with challenges facing international trade due to fast developing technology and communication methods by addressing: 1) introducing negotiation of document under letter of credit 2) application of UCP to Deferred Payment LCs and Standby LCs and 3) Using SWIFT for transmission of documents and LC [36]. Further revision of UCP was adopted in ICC conference in Mexico in 1993 and came into force by first 
Hamed Alavi (2016)

Documentary Letters of Credit, Legal Nature and Sources of Law

January 1994 [37]. It is known as UCP 500 which was an improvement to UCP 400. It introduced the notion of nominated bank [38], bank duty to examine documents [39] and their rejection [40] new provisions regarding documents (articles 23-30, on transport documents, article 34-36 on insurance documents, and article 37 on commercial invoice). Finally, the current revision of UCP known as UCP 600 came into force in 2007 and brought about further developments in international LC operation. UCP 600 can be named as the most trade friendly among all versions of Unified Customs and Practices for Documentary Letters of Credit [41]. Also by many scholars considered UCP 600 as a forward movement in harmonisation of LC regulations in international trade [42]. Main developments in UCP 600 in comparison with former versions can be categorized as: Introducing UCP articles as Rule for the first time [43], reducing number of articles from 49 in UCP 500 to 39 in UCP 600, providing more clarification by defining honour, negotiation and presentation [44], not recognition of revocable Documentary Letters of Credit [45], defining new standard of examination of documents by bank [46], clarification of the role of banks in deferred payment system [47], identification of careers and agent [48], providing clarity about documents relevant to multimodal transport [49] and finally, providing clear definition for original document [50].

UCP has no legislative authority [51], as it is neither a convention nor ICC is a governmental organization [52]. Therefore, despite the fact that its introduction in Article 1 of UCP 600 as "rules", we can consider it as globally recognized banking customs and practices which are only applicable to Documentary Letters of Credits through incorporation [53]. UCP was developed due to the need for recognition of uniform procedures which could harmonize the practice of Documentary Credit at global level [54].

\section{eUCP}

"This is the acronym for the supplement to the uniform Customs and Practice for Documentary Credits for Electronic Presentation" [55]. Meeting the needs for electronic trade was the initiative of Banking Commotion of ICC to propose the formation of committee to work on developing a bridge between UCP and processing the electronic equivalent of paper based credits the working group started to work on preparation of a supplement to the UCP which "would deal with the issues of Electronic Presentation" [56]. The result of working group's efforts is known as eUCP. It came into force from 1 April 2002 and in the format of version issues in order to facilitate the necessities for further revisions [57]. Current version of eUCP is the version 1.1. Issues covered by eUCP are: "eUCP- UCP relations, format, presentation, originals and copies and examination of electronic records" [58]. Article 2 of eUCP emphasized on consistency of the all articles of eUCP with UCP while their application is only in case of electronic presentation. While using 

of it [59].

\subsubsection{Uniform Rules of Contract Guarantees (URCG)}

URCG was introduced by ICC in early 1970s in order to address the need for set of rules which deal with existing inconsistencies in field of "[g]uarantees given by banks, insurance or services or the performance of work." [60]. Therefore, unlike UCP which was regulating the process of Letter of Credit URCG was an attempt to deal with unfair calls for demand guarantees. Despite all expectations, URCG was not welcomed by the international business society for few reasons including: the problem that applicability of URCG was only limited to independent guarantees and it had no effect on accessory guarantees [61].

The other problem was the result of URCG's attempt to prevent unfair call on demand guarantees by requiring beneficiary to produce an evidence of failure in the format of judgement, arbitral award or the principal's written approval at the time of making the claim [62].

\subsubsection{Uniform Rules for the Demand Guarantees (URDG)}

The failure of URCG in attracting the attention of the business society at global level was the reason for ICC to introduce new set of rules and take a different approach to Demand Guarantees. URDG 458 came into force by 1992 and based on a model which was applied by British Bankers [63]. Despite the fact that URDG 458 was strongly influenced by UCP, but still "[w]orldwide acceptance of the Rules ha[s] been disappointing" [64]. URDG 758 which is the revised version of URDG 458 came into force on 1 July 2010 .It tries to address problems of previous version and set out functions and obligations of parties to the demand- guarantee by reflecting the best practices in business of guarantees. [65]

\subsubsection{International Standard Practice (ISP 98)}

"ISP.98 is a set of rules specifically designed for standby letters of credit" [66]. It was originally introduced by American institute of International Banking Law and Practice. ISP 98 received approval by ICC in 1998 [67] and came into effect by January 1999. Historically, Standby Letters of Credits have been in use for many decades without being subjected to specific regulations. They were mostly regulated by UCP, however, application of UCP to Standby Letters of Credits was source of many problems as UCP was "originally written for use only in commercial letters of credit... many of the provisions of the U.C.P. are either inapplicable or inappropriate in a standby credit context." [68]. On the other hand, it was possible for Standby Letters of Credit to be governed by URDG due to similarity between legal character of Demand Guarantees and Standby Letters of Credits. However, URDG is becoming more popular after coming into force of its 
Hamed Alavi (2016)

Documentary Letters of Credit, Legal Nature and Sources of Law

new revision URDG 758 and "[f]rom the viewpoint of the I.C.C ... Standby letters of credit continue to be covered by the U.C.P. and are not covered by the U.R.D.G." [69] Initially, similar to UCP for regulating the function of Commercial Letters of Credits URDG for Independent Guarantees, and ISP 98 was drafted for the purpose of regulating Standby Letters of Credits. However, "Like the UCP and the URDG, ISP98 [applies] to any independent undertaking issued subject to it" [70].

\subsubsection{International Standard Banking Practice for the Examination of the} Documents under Documentary Credits Subject to UCP 600 (ISBP)

ISBP has been described by ICC as a great help to banks, corporates, logistics specialists and insurance companies [71]. The main idea behind introducing it is the explanation of how to apply UCP in practice. For example, 185 sections of ISBP comment on documents which are not covered by UCP [72], expressions which are not defined in UCP [73], management of misspelling and specific types of errors [74]; time for application of original and copies [75]; methods of signing documents [76]; and how to prepare insurance documents [77].

\subsubsection{Uniform Rules for Bank to Bank Reimbursement under Documentary Credits}

ICC introduced the URR 525 in order to standardize the bank to bank reimbursement process. Article 13(b) which is new in UCP 600 aligns it with URR 525 [78]. The last renewal process of URR took place in 2008 by replacing URR 525 with URR 725. According to ICC, URR 725 should not be considered as the revision of URR 525 as it is more an update in order to be in more alignment with UCP 600 [79]. Since URR 725 has not been incorporated into UCP 600, its application is only limited to bank to bank reimbursement based on explicit agreement to the reimbursement agreement [80].

Article 13(b) of UCP 600 will cover bank reimbursement obligations in absence of such provisions in reimbursement agreement.

\subsubsection{United Nation's Convention on Independent Guarantees and Standby Letters of Credits}

UNCITRAL Convention has been drafted by an intergovernmental organization which is body of United Nations General Assembly and works on preparation of instruments for harmonization of law regarding international trade [81]. Convention has been adopted by UN General Assembly on 11 December of 1995 [82]. Standby letters of credits and independent guarantees or any other international undertaking can be subjected to the UCITRAL Convention [83]: "the place of business of the guarantor/issuer at which the undertaking is issued is in a Contracting State," or "the rules of private law lead to the application of the law of 
a Contracting State," "unless the undertaking excludes the application of the Convention."

In case of Commercial Letters of Credit, by express address of parties to the credit UNCITRAL Convention can be used as the governing law [84]. Although, UCP and URDG have been used as bases for drafting the UNCITRAL Convention, it is possible to distinguish some differences among them. First, UCP and URDG have been drafted by ICC which is a private institute and its approvals might only have application as voluntary rules or self-regulations while UNCITRAL Convection is a uniform law and official regulation applied to signatory countries which has been drafted by an international organization [85]. Therefore, UNCITRAL Convention can be differentiated from ICC rules due to its legal statues. In addition, UNCITRAL Convention, consist of complementary provisions to UCP 600, URDG and ISP 98 including abusive demand, fraud and remedies which are discussed under the section 19 of Convection.

\subsubsection{Unified Commercial Code}

Among the common law jurisdictions, United States of America is the only country which a detailed regulations on Documentary Letters of Credits under the Article 5 of UCC: "The U.C.C. is a collection of model statutes drafted and recommended by the National Conference of Commissioners of Uniform State Laws (NCCUSL) and the American Law Institute (A.L.I.) for enactment by the legislatures of the states of the United States. It consists of eleven different articles, each covering a different aspect of commercial law" [86]. Article 5 of the UCC was drafted for the first time during 1950s when it was intended to act as an "independent theoretical framework for the further development of letters of credit." [87] Article 5 of UCC was revised in 1995 almost after forty years of hard use [88] in order to overcome "weaknesses, gaps and errors in the original statute which compromise its relevance" [89]. The revised Article 5 of UUC which was completed in October 1995 and it was almost adopted by all states in 2002. Despite the presence of Article 5 of UCC, still UCP has great influence of American regulations of Documentary Letters of Credits [90]. According to the official commentary to article 5: "Article 5 of UCC and UCP are consistent and complementary to UCP in many occasions". However, they have substantial differences as well. Firstly, Article 5 of UCC has been drafted as a Statue while neither ICC regulations including UCP have such effect. Secondly, in accordance with UNCITRAL Convention, article 5 comments on fraud rule which has been left open by UCP [91].

\section{National Laws}

There are few counties expect the United States of America which enjoy the national statuary provisions on Documentary Letters of Credit. Among them 
Hamed Alavi (2016)

Documentary Letters of Credit, Legal Nature and Sources of Law

Greece was the first country to adapt such low in 1923 [92]. Italy is the other European country which regulates LC operation under article 1530 of its Civil Code by defining rights of account party and beneficiary. It also clarifies bank's rights and obligations [93]. Some South Amirian counties including Bolivia, Colombia, Guatemala, Honduras, Mexico and El Salvador also have their own national statute for regulating LC operation [94]. In the Middle East, most of countries are influenced by Lebanese Law and Kuwaiti Law. Lebanese Law which is followed in Qatar [95] and Syria [96] regulates operation of Documentary Letters of Credit under article 313 of its Commercial Code [97]. Kuwaiti Law which is adapted in Iraq [98] and Bahrain [99] is the most comperhenveive and modern statuary law of Documentary Credits [100] which covers areas of expiry date, transfer and assignment of the credit, confirmation, fraud, duty of examination of documents by bank, definition of comprehensive presentation and autonomy principle under its articles.

\section{Conclusion}

The development of letter of credit goes back to the demand of mercantile practice in the course of time. There is no doubt about similarities between legal characters of Letters of Credits, Negotiable Instruments and Contracts, however, unique nature of their Jurisprudence should not be confuses with the latter.

As a result, all involved practitioners in the area of international trade law and international trade finance should keep in mind similarities and differences between Letters of Credits and other financial Instruments. Legal nature of Letters of Credits are covered mostly in the framework of Unified Customs and Practices for Documentary Letters of Credits (UCP), eUCP, URCG, URDG, ISP98, UNCITRAL Convention, ISBP and Uniform Rules for Bank to Bank Reimbursement under Documentary Credits. In United States of America, Article 5 of the UCC governs legal aspects of Documentary Letters of Credit Operation. Additionally, matters related to principles of strict compliance and autonomy as well as exceptions to autonomy principle are covered mostly by domestic law of respective jurisdiction. This can be considered as the most important difference between legal nature of Documentary Letters of Credit, Negotiable Instruments and Contracts which should be kept in mind by all legal practitioners involved in Letter of Credit Operations

\section{Notes}

[1] RD Harbottle (Mercantile) Ltd v National Westminster Bank Ltd (1978) QB 146, 155 (Kerr LJ); Power Curber International Ltd v National Bank of Kuwait SAK (1981)2; Lloyd's Rep 394,400 (Griffiths LJ); Intraco Ltd v Notis Shipping Corporation of Liberia; The Bhoja Trader (1981)2 Lloyd's Rep 256, 257 (Donaldson LJ); Hong Kong and Shanghai Banking Corporation v Kloecker \&Co AG (1989)2 Lloyd's Rep 323,330 (Hirst J) 
Hamed Alavi (2016)

Documentary Letters of Credit, Legal Nature and Sources of Law

[2] Garcia RLF 'Autonomy principle of the letter of credit' (2009) Mexican Law Review 72 (Hereafter Garcia RLF (2009).

[3] Trimble RF 'The Law Merchant and the Letter of Credit', (1948) 61 Harvard Law Review, 982-86.

[4] Toth. Z, 'Documentary Credits in the International Commercial Transaction with Special Focus on Fraud Rule' (2006) ,1, Doctoral Dissertation

[5] Koudriachov. SA, (2001), Application of the Letter of Credit Form of Payment in the International Business Transactions. 10. Current International Trade Law Journal. 37

[6] De Roover. R, Money, Banking and Credit in Medieval Bruges, 2 Journal of Economic History (Suppl. Issue), 1942, p.52

[7] Kozolchyk, B. Commercial Letter of Credit in the Americas: A Comparative Study of Contemporary Commercial Transactions. Bender, (1966). 4.

[8] Goode.R, 'Abstract Payment Undertakings' in Peter Cane and Jane Stapleton (eds), Essays for Patrick Atiyah (OUP 1991

[9] Article 2, UCP 600

[10] Supra Note 5

[11] Garcia RLF (2009). 69

[12] Pillans and Rose Vs Van Mierop and Hopkins (1756) 97, English. Rep. 1035 (BURR 1666)

[13] Mc Curdy .W, 'Commercial Letters of Credit' (1922) , Harvard Law Review, 539

[14] Article 2 UCP 600

[15] Article 9.a, UCP 600

[16] Gian Singh and Co Ltd v Banque de l'Indochine [1974] 1 WLR 1324, 1238

[17] UCP 600 -Article 2

[18] Enonchong. N., 'The Independence Principle of Letters of Credits and Demand Guarantees', Oxford University Press, (2011). 9

[19] Ibid. 8

[20] Article 7- UCP 600.

[21] Längerich R 'Documentary Credits in Practice' (2000) 106

[22] Artcle 7( C), UCP 600

[23] Längerich R (2000) 104

[24] Xiang, Gao, and Ross P. Buckley. "Unique Jurisprudence of Letters of Credit: Its Origin and Sources." San Diego Int'l LJ 4 (2003): 104

[25] Harfield. H, and Ward .W, Bank credits and acceptances. Ronald Press Company, 1974.158-62

[26] Gao Xiang (2003). 105

[27] Kozolchyk, B. 1966, 4

[28] Ellinger, Eliahu Peter. Documentary letters of credit: a comparative study. University of Singapore Press, (1970). 6-7.

[29] E.P. Ellinger, Letter of Credit, Schmitthoff, C. M., \& Horn, N. (Eds.). (1982). The transnational law of international commercial transactions. Kluwer. P.248

[30] Ibid

[31] Taylor .D (1999), The History of the UCP, DOCUMENTARY CREDIT WORLD, 11, reprinted in 2000 ANNUAL SURVEY 201. 
Hamed Alavi (2016)

Documentary Letters of Credit, Legal Nature and Sources of Law

[32] Chung, S. Isabella. "Developing a Documentary Credit Dispute Resolution System: An ICC Perspective." Fordham Int'l LJ 19 (1995): 1355

[33] Ellinger, E. P. (1970). Documentary letters of credit: a comparative study. University of Singapore Press, p. 580

[34] ICC publication no 290

[35] ICC Publication no 434.

[36] Xiang, G., 2002. The Fraud Rule in the Law of Letters of Credit: A Comparative Study. The Hague, p.16-17.

[37] ICC publication no 500.

[38] UCP 500, Article 10(b)

[39] UCP 500, Atrticle 13(a)

[40] UCP 500, Article 14

[41] Rodrigo, T., 2011. UCP 500 to 600: A forward movement. eLaw J., 18, p.20

[42] Ibid

[43] UCP 600, Article 1

[44] UCP 600, Article 2

[45] Ibid

[46] UCP 600, Article 14

[47] UCP 600, Article 7

[48] UCP 600, Article 14

[49] UCP 600, Article 19

[50] UCP 600, Article 17

[51] Ademola, AO 'Letters of Credit: Tower of Babel or Jacob's ladder? A Look at Whether Private Codifications of Commercial Usage Brings Us Any Closer to a Harmonised International Commercial Law (2008) (http://www.dundee.ac.uk/cepmlp/ gateway/index.php?news=29287, accessed on 15 July 2015)) 6

[52] Forewords to UCP 600

[53] ICC Brochure No 82

[54] UCP 600 Introduction. 11

[55] Gao X \& Buckley RP (2003) .113.

[56] Ibid

[57] Gao X \& Buckley RP (2003) .114

[58] Ibid

[59] Ibid

[60] INT'L CHAMBER OF COMMERCE, ICC PUBLICATION No. 325 (1978). 7.

[61] Gao X \& Buckley RP (2003) 114

[62] URCG , Article 8(3) and 9

[63] INT'L CHAMBER OF COMMERCE, ICC PUBLICATION No. 458

[64] Katz.R, Report delivered at the I.C.C. Hong Kong meeting, reprinted in INT'L CHAMBER OF COMMERCE, ICC PUBLICATION No. 470/893, 19

[65] Baranello J 'Understanding the URDG 758'(2010) (http://www.fpsc.com/DB/ TreasuryPulse/ Fall2010/Article4.html, accessed on 15 July 2015).

[66] Gao X \& Buckley RP (2003) ,115

[67] INT'L CHAMBER OF COMMERCE, ICC PUBLICATION No. 590 (1998) 
Hamed Alavi (2016)

Documentary Letters of Credit, Legal Nature and Sources of Law

[68] Turner, P.S. 'New Rules for Standby Letters of Credit: The International Standby Practices' (1999) 14. Banking \& Finance Law Review 459

[69] INT'L CHAMBER OF COMMERCE, ICC PUBLICATION No. 205-207 (1998)

[70] James E. Byrne, Preface to JAMES E. BYRNE ET AL., INTERNATIONAL STANDBYPRACTICES ISP98 6. (ICC Publishing, Inc. 1998)

[71] Introduction of ISBP

[72] sections 19-20 ISBP

[73] section 21 of ISBP

[74] section 25 of ISBP

[75] sections 28-33 ISBP

[76] sections 37-40 ISBP

[77] sections 170-180 ISBP

[78] UCP 600, Article 13 (b): '[i]f a credit does not state that reimbursement is subject to the ICC rules for bank-to-bank reimbursements, the following apply: (...)

[79] Introduction to URR 725

[80] URR 725, Article 1

[81] Explanatory Note: UNCITRAL Secretariat on the United Nations Convention on Independent Guarantees and Stand-by Letters of Credit, U.N. Commission on International Trade Law, 30th Sess., note I, at 2, U.N. Doc. A/CN.9/431 (1996)

[82] Gao X \& Buckley RP (2003) .117

[83] UNCITRAL CONVENTION art. 1(2)

[84] UNCITRAL CONVENTION art. 1(1)(b).

[85] UNCITRAL CONVENTION art. 1(2)

[86] Grassi PS 'Letter of Credit Transactions: The Banks' Position in Determining Documentary Compliance. A Comparative Evaluation under U.S., Swiss and German Law' (1995) Pace International Law Review 106

[87] Gao X \& Buckley RP (2003). 117

[88] Original U.C.C. art. 5, § 5-101, Official Comment 1 (1995)

[89] Task Force on the Study of U.C.C. Article 5, Report, An Examination of U.C.C. Article 5 (Letters of Credit), 45 Bus. LAW 1521, 1532 (1990)

[90] Barski. Katherine A, 'Letters of Credit: A Comparison of Article 5 of the Uniform Commercial Code and the Uniform Customs and Practice for Documentary Credits', 41 LOY. L. REV. 735, 739 (1996)

[91] Buckley. RP, Documentary Compliance in Documentary Credits: Lessons from the UCC for the UCP, 1 J. INT'L COM. L. 60, 69 (2002).

[92] Ellinger .P \& Noe.D, (2010), 58

[93] Ballosini, Il Credito Documentario (1978), Rome, vol 11, 981.

[94] Ellinger. P, Noe, D., (2010), 58.

[95] Article 348 of Civil and Commercial Code of 1971

[96] Article 408 of the Commercial Code, Law Number 149 of 1949.

[97] Law Number 304 of 1942.

[98] Article 273-284 of the commercial code, Law Number 30 of 1984.

[99] Commercial Code, Law Number 7 of 1987, Article 217-36.

[100] Ellinger, P., Noe, D. (2010), 59. 
Hamed Alavi (2016)

Documentary Letters of Credit, Legal Nature and Sources of Law

\section{Bibliography}

1. Ademola, A.O. (2008), Letters of Credit: Tower of Babel or Jacob's ladder? A Look at Whether Private Codifications of Commercial Usage Brings Us Any Closer to a Harmonised International Commercial Law (http://www.dundee.ac.uk/ cepmlp/ gateway/index.php?news=29287, accessed on 15 July 2015)

2. Arkins, J.R.C. (2000), Snow White v. Frost White: the new cold war in banking law, Journal of International Banking Law, J.I.B.L. 2000, 15(2), 31

3. Baker, B., Exporting Against Letters of Credit, available at http://www.qfinance.com/content Files/QF02/g1xtn5q6/12/3/exporting-againstletters-of-credit.pdf (visited 15 July 2015)

4. Baranello, J. (2010), Understanding the URDG 758 (http://www.fpsc.com/DB/ TreasuryPulse/ Fall2010/Article4.html, accessed on 15 July 2015)

5. Barski, K.A. (1996), Letters of Credit: A Comparison of Article 5 of the Uniform Commercial Code and the Uniform Customs and Practice for Documentary Credits, 41 LOY..L. REV. 735, 739

6. Botosh, H.M.S. (2002), Striking the Balance Between the Consideration of Certainty and Fairness it the Law Governing Letters of Credit, 183-271

7. Buckley, R.P. (2002), Documentary Compliance in Documentary Credits: Lessons from the UCC for the UCP, 1 J. INT'L COM. L. 60, 69

8. Chuah, J. (2009), Law of International Trade, $4^{\text {th }}$ edn, Sweet \& Maxwell, p. 436.

9. Chung, S. I. (1995), Developing a Documentary Credit Dispute Resolution System: An ICC Perspective, Fordham Int'l LJ 19 (1995): 1355

10. De Roover. R. (1942), Money, Banking and Credit in Medieval Bruges, 2 Journal of Economic History (Suppl. Issue), 1942, p.52.

11. Ellinger, E.P. (1970), Documentary letters of credit: a comparative study. University of Singapore Press, 6-7.

12. Enonchong, N. (2011), The Independence Principle of Letters of Credits and Demand Guarantees, Oxford University Press, 9

13. Eakin v Continental Illinois National Bank \& Trust Co. (1989) 875F.2d114.116 14. Garcia, R.L.F. (2009), Autonomy principle of the letter of credit, Mexican Law Review 72

15. Goode. R. (1991), Abstract Payment Undertakings, in Peter Cane and Jane Stapleton (eds), Essays for Patrick Atiyah (OUP 1991).

16. Grassi, P.S. (1995), Letter of Credit Transactions: The Banks' Position in Determining Documentary Compliance. A Comparative Evaluation under U.S., Swiss and German Law' (1995) Pace International Law Review 106

17. Harfield, H., Ward, W. (1974), Bank credits and acceptances, Ronald Press Company, 158-62

18. Hotchkiss, C. (1991), Strict Compliance in Letter-of-Credit Law: How Uniform is the Uniform Commercial Code? 23 Uniform Commercial Code Law Journal 295 
Hamed Alavi (2016)

Documentary Letters of Credit, Legal Nature and Sources of Law

19. James, E.B. (1998), Preface to J.E. Byrne et al., International standbypractices ISP98, 6. (ICC Publishing, Inc. 1998)

20. Katz, R., Report delivered at the I.C.C. Hong Kong meeting, reprinted in INT'L Chamber of Commerce, ICC Publication No. 470/893, 19

21. Krazovska, D. (2008), Impact of the Doctrine of Strict Compliance on a Letter of Credit Transaction, Master Thesis, University of Aarhus, 25-43

22. Koudriachov, S.A. (2001), Application of the Letter of Credit Form of Payment in the International Business Transactions, 10. Current International Trade Law Jurnal, 37.

23. Kozolchyk, B. (1996), Commercial Letter of Credit in the Americas: A Comparative Study of Contemporary Commercial Transactions, Bender, 4.

24. Kozolchyk, B. (1980), Commercial Letter of Credit in the Americas: A Comparative Study of Contemporary Commercial Transactions. Bender.10

25. Kozolchyk, B. (1965), The Legal Nature of the Irrevocable Commercial Letter of Credit, 14 American Journal of Comparative Law, 1965, p.395 - 398

26. Längerich, R. (2000), Documentary Credits in Practice, 106

27. King, R., Gutteridge and Megrah's Law of Bankers' Commercial Credits, p. 14, 28. Rodrigo, T. (2011), UCP 500 to 600: A forward movement, eLaw J., 18, p.20

29. Toth, Z. (2006), Documentary Credits in the International Commercial Transaction with Special Focus on Fraud Rule, 1, Doctoral Dissertation.

30. Trimble, R.F. (1948), The Law Merchant and the Letter of Credit, 61 Harvard Law Review, 982-86.

31. Turner, P.S. (1999), New Rules For Standby Letters of Credit: The International Standby Practices, 14. Banking \& Finance Law Review 459

32. UCP 600 , ICC Publication 2007

33. Ward Petroleum Corp. v Federal Deposit Ins. Corp. (1990) 903 F.2d 1299

34. Wight, R., Ward, A. (1993), The Advising Bank in Letter of Credit Transactions and the Assumption of Agency, Journal of International Banking Law 432

35. Xiang, G., Ross, P.B. (2003), Unique Jurisprudence of Letters of Credit: Its Origin and Sources, The "San Diego Int", 1 LJ 4 (2003): 104 